Article

\title{
Cloning, overexpression, and characterization of a novel organic solvent-tolerant lipase from Paenibacillus pasadenensis CS0611
}

\author{
Jiaxin Gao a , Xiaoyang $\mathrm{Ou}$ a, Pei Xu a , Minhua Zong b, Wenyong Lou a,b,* \\ a Laboratory of Applied Biocatalysis, School of Food Science and Engineering, South China University of Technology, Guangzhou 510640, \\ Guangdong, China \\ b State Key Laboratory of Pulp and Paper Engineering, South China University of Technology, Guangzhou 510640, Guangdong, China
}

\section{A R T I C L E I N F O}

\section{Article history:}

Received 20 November 2017

Accepted 19 January 2018

Published 5 May 2018

\section{Keywords:}

Lipase

Paenibacillus pasadenensis CS0611

Expression

Characterization

Organic solvent tolerant

\begin{abstract}
A B S T R A C T
We found a novel lipase gene in the Paenibacillus pasadenensis CS0611 strain. The lipase gene sequence was cloned into the pET-28a expression vector to construct a recombinant lipase protein containing $6 \times$ His tags at the $\mathrm{C}$ - and N-termini, respectively. High-level expression of the lipase in E.coli BL21 (DE3) was obtained upon induction with IPTG at $20^{\circ} \mathrm{C}$. The recombinant lipase activity was approximately 1631-fold higher than the wild type. His-tagged recombinant lipase was purified rapidly and efficiently by using $\mathrm{Ni}$-charged affinity chromatography with $63.5 \%$ recovery and a purification factor of 10.78 . The purified lipase was stable in a broad range of temperatures and $\mathrm{pH}$ values, with the optimal temperature and $\mathrm{pH}$ being $50{ }^{\circ} \mathrm{C}$ and 7.0 , respectively. Its activity was stimulated to different degrees in the presence of metal ions such as $\mathrm{Ca}^{2+}, \mathrm{Mg}^{2+}$, and some non-ionic surfactants. In addition, the purified lipase was activated by a series of water-miscible organic solvents such as some short carbon chain alcohols and was highly tolerant to some water-immiscible organic solvents.
\end{abstract}

(C) 2018, Dalian Institute of Chemical Physics, Chinese Academy of Sciences. Published by Elsevier B.V. All rights reserved.

\section{Introduction}

Lipases (E.C 3.1.1.3) catalyze the hydrolysis of medium- and long-chain triglycerides, and a major characteristic is the sharp activation at the interface generated by a water-insoluble lipid substrate in aqueous solution [1]. Lipases can also catalyze ester synthesis and transesterification reactions with high regional and stereoselectivity in nonaqueous solvent systems [2-4]. These features allow lipases to be the most widely used enzymes in synthetic detergent additives, fine chemicals, and for precursors of chiral pharmaceutical and agrochemical production [5-7].

Organic solvents are usually utilized instead of water in some lipase-catalyzed reactions. There are many advantages that anhydrous organic solvents can offer, such as shifting the equilibrium to the synthetic direction, controlling or modifying enzyme selectivity by solvent engineering, increasing the solubility of substrates and the recovery of products in the organic phase, improving the thermal stability of enzymes, and suppressing undesirable water-dependent side reactions $[8,9]$. However, organic solvents affect the activity and stability of enzymes to different degrees. Therefore, lipases that show high activity and stability in organic solvents are of interest [10-13].

At present, research on microbial lipases has mainly focused on strains with industrial application value such as Rhizopus, Aspergillus, Candida, Pseudomonas, and Bacillus [14-16]. There

\footnotetext{
* Corresponding author. Tel/Fax: +86-20-22236669; E-mail: wylou@scut.edu.cn This work was supported by the National Natural Science Foundation of China $(21336002,21376096,21676104)$ and the Program of State Key Laboratory of Pulp and Paper Engineering (2017ZD05).

DOI: 10.1016/S1872-2067(18)63033-5 | http://www.sciencedirect.com/science/journal/18722067 | Chin. J. Catal., Vol. 39, No. 5, May 2018
} 
are few studies and reports on lipases from Paenibacillus. $P$. pasadenensis CS0611 was previously isolated from soils around chitin biological production factories in Shandong China and identified based on morphological characterization and 16s rDNA sequence analysis. The present paper describes the cloning, heterogeneous expression, and purification of a novel organic solvent-tolerant lipase from this strain. Consequently, detailed enzymatic properties of the recombinant enzyme were studied.

\section{Experimental}

\subsection{Bacterial strains, plasmids, enzymes, and reagents}

P. pasadenensis CS0611 was isolated by our group previously and stored at the China Center for Type Culture Collection (CCTCC M2014458). KOD FX (Toyobo, Japan) was used for PCR; pET-28a vector (Novagen, Germany) was used for the cloning, sequencing, and expression experiments; E. coli BL21 (DE3) was used as the expression host. Restriction enzymes Fast Digest Sal I and BamH I, T4 DNA ligase, and DNA and protein markers were purchased from Thermo Fisher Scientific (Wilmington, DE, USA). Synthesis of the primers and DNA sequencing were completed by Invitrogen (USA). The kits used in the construction of recombinant plasmids were purchased from Generay (Shanghai, China). Substrates ( $p$-nitrophenyl fatty acid esters with varying acyl chain lengths), isopro-pyl- $\beta$-D-thiogalactopyranoside (IPTG), and kanamycin were purchased from Sigma-Aldrich (St. Louis, MO) or Aladdin (Shanghai, China). All other reagents and solvents were of analytical grade and used without further purification.

\section{2. $\quad$ Cloning and sequencing of gene lp2252}

The cloning and transformation of the target gene were according to the methods described by Sambrook et al [17]. $P$. pasadenensis CS0611 was grown in Luria-Bertani (LB) medium ( $1 \%$ tryptone, $0.05 \%$ yeast extract, $1 \% \mathrm{NaCl}$ ) at $37{ }^{\circ} \mathrm{C}$ for about $15 \mathrm{~h}$, and the genomic DNA was extracted and purified using a bacterial genomic DNA Kit according to the manufacturer's instructions. Two primers F1(5'-CGCGGATCCATGCGGAAGCAAAGCGAAAAGGA-3') and R1(5'-GCGTCGACAGAGTTTGCATAAATCCACATCTTGACCG-3') were designed based on the nucleotide sequences immediately upstream and downstream the known coding sequences of lp2252 and introduced BamH I and Sal I restriction sites in the 5' and 3' ends of the complete gene, respectively (underlined sequences correspond to the restriction sites). The amplification of the lp2252 gene was carried out by KOD FX DNA Polymerase using genomic DNA as a template. The PCR amplification was performed with the following cycles: one cycle of pre-denaturation at $94{ }^{\circ} \mathrm{C}$ for $2 \mathrm{~min} ; 30$ cycles of $98^{\circ} \mathrm{C}$ for $10 \mathrm{~s}$ (denaturation), $45^{\circ} \mathrm{C}$ for $30 \mathrm{~s}$ (annealing), and $68^{\circ} \mathrm{C}$ for $1.5 \mathrm{~min}$ (extension); followed by one cycle of final extension at $68^{\circ} \mathrm{C}$ for $7 \mathrm{~min}$. The purified PCR product was digested with BamH I and Sal I, and inserted into the expression vector pET-28a previously digested with the same restriction enzymes to obtain the recombinant plasmid pET-28a-lp2252. The recombinant plasmid was transformed into E. coli BL21 (DE3) competent cells using heat shock. The transformed cells were plated on LB agar ( $1 \%$ tryptone, $0.05 \%$ yeast extract, $1 \% \mathrm{NaCl}, 2 \%$ agar) containing kanamycin $(50 \mu \mathrm{g} / \mathrm{mL})$ and incubated at $37^{\circ} \mathrm{C}$ overnight. The positive transformed colonies were confirmed by sequencing after the plasmid extraction (using a high purity plasmid preparation kit according to manufacturer's instructions).

\subsection{Expression and purification of recombinant lp2252}

The recombinant cells were cultivated in $20 \mathrm{~mL}$ LB medium containing $50 \mu \mathrm{g} / \mathrm{mL}$ of kanamycin at $37^{\circ} \mathrm{C}, 180 \mathrm{r} / \mathrm{min}$ for $12 \mathrm{~h}$. A 250-mL flask containing $100 \mathrm{~mL}$ LB broth medium supplemented with $50 \mu \mathrm{g} / \mathrm{mL}$ kanamycin was inoculated with $1 \%$ $(v / v)$ of pre-cultured cells described above. Different concentrations of IPTG were added as an inducer at different OD600 values, and the cultivation continued at different temperatures to determine the optimum induction conditions. Recombinant cells were harvested by centrifugation ( $8000 \mathrm{r} / \mathrm{min}, 5 \mathrm{~min}$ ) at 4 ${ }^{\circ} \mathrm{C}$. The cell pellet was suspended in $20 \mathrm{mmol} / \mathrm{L}$ phosphate buffer, pH $7.5(10 \mathrm{~mL})$. After ultrasonic disruption and centrifugation, the supernatant was filtered through a membrane filter with a pore size of $0.45 \mu \mathrm{m}$ and applied to a Bio-Scal ${ }^{\mathrm{TM}}$ Mini Nuvia TM IMAC Ni-charged column (5 mL, Bio-Rad, USA). The column was washed with 10 volumes of distilled water. After equilibration with 10 volumes of binding buffer $(20$ mmol/L phosphate buffer, $500 \mathrm{mmol} / \mathrm{L} \mathrm{NaCl}$, and $10 \mathrm{mmol} / \mathrm{L}$ imidazole, $\mathrm{pH}$ 7.5), $5 \mathrm{~mL}$ of the crude enzyme preparation was loaded onto the column. The column was washed with 20 volumes of washing buffer $(20 \mathrm{mmol} / \mathrm{L}$ phosphate buffer, 500 $\mathrm{mmol} / \mathrm{L} \mathrm{NaCl}$, and $20 \mathrm{mmol} / \mathrm{L}$ imidazole, $\mathrm{pH}$ 7.5). The target protein was eluted with a $20-500 \mathrm{mmol} / \mathrm{L}$ imidazole gradient at a flow rate of $0.3 \mathrm{~mL} / \mathrm{min}$ with elution buffer $(20 \mathrm{mmol} / \mathrm{L}$ phosphate buffer, $500 \mathrm{mmol} / \mathrm{L} \mathrm{NaCl}$, and $500 \mathrm{mmol} / \mathrm{L}$ imidazole, $\mathrm{pH}$ 7.5). The active fraction was collected and concentrated with an ultra-filtration membrane $(10 \mathrm{kDa}$, Millipore, Billerica, MA). The purity of lp2252 was analyzed by sodium dodecylsulfate-polyacrylamide gel electrophoresis (SDS-PAGE) as described by Sambrook et al. [17].

\subsection{Enzyme and protein assays}

Lipase activity was determined using $p$-nitrophenyl fatty acid esters as substrates [18]. The standard assay reaction mixture contained $20 \mathrm{mmol} / \mathrm{L}$ phosphate buffer (400 $\mu \mathrm{L}, \mathrm{pH} 7)$, $10 \mathrm{mmol} / \mathrm{L} p$-NPC 16 dissolved in isopropanol $(50 \mu \mathrm{L})$, and purified enzyme ( $50 \mu \mathrm{L}$ ). $500 \mu \mathrm{L}$ of $0.5 \mathrm{~mol} / \mathrm{L} \mathrm{Na}_{2} \mathrm{CO}_{3}$ was added to the reaction mixture after $5 \mathrm{~min}$ at $50^{\circ} \mathrm{C}$ to terminate the reaction. One unit $(\mathrm{U})$ of enzymatic activity is defined as the amount of enzyme required to produce $1 \mu \mathrm{mol}$ of $p$-nitrophenyl per min ( $\varepsilon 410 \mathrm{~nm}=0.016 \mu \mathrm{L} / \mathrm{mol})$. Unless specially mentioned, all measurements of lipase activity were conducted under standard conditions. Protein concentration was determined using the Bradford method with bovine serum albumin as the standard [19]. All assays were performed in triplicate and average 
values were taken.

\subsection{Effect of temperature and $p H$ on enzyme activity and stability}

The optimal temperature for activity was determined by measuring the hydrolytic activity at different temperatures $\left(20-70{ }^{\circ} \mathrm{C}\right)$. Thermostability was determined by measuring residual activity after incubation of the purified enzyme at temperatures ranging from 20 to $60^{\circ} \mathrm{C}$ for different time intervals. The optimal $\mathrm{pH}$ was determined similarly at $50{ }^{\circ} \mathrm{C}$ in 50 $\mathrm{mmol} / \mathrm{L}$ buffer solutions of $\mathrm{pH}$ values ranging from 2.0 to 10.0 (glycine-HCl: 2.0-3.0; HAc-NaAc: 3.0-5.0; $\mathrm{Na}_{2} \mathrm{HPO}_{4}$-citric acid: 5.0-8.0; Tris-HCl: 8.0-9.0; glycine-NaOH: 9.0-10.0). The effect of $\mathrm{pH}$ on enzyme stability was investigated by measuring the residual activity after pre-incubation of purified enzyme for different time intervals at $4{ }^{\circ} \mathrm{C}$ in $\mathrm{Na}_{2} \mathrm{HPO}_{4}$-citric acid buffer solutions (50 mmol/L, pH 3.0-8.0).

\subsection{Effects of metal ions, surfactants, and inhibitors on enzyme activity}

The effect of various metal ions, surfactants, and inhibitors on the lipase activity was determined by investigating the residual activity after incubating the purified lipase in phosphate buffer (20 mmol/L, pH 7.0) containing the following chemical agents at $30{ }^{\circ} \mathrm{C}$ for $30 \mathrm{~min}$ : Metal ions $(2 \mathrm{mmol} / \mathrm{L}): \mathrm{Ca}^{2+}, \mathrm{Mg}^{2+}$, $\mathrm{Cu}^{2+}, \mathrm{Zn}^{2+}, \mathrm{Fe}^{2+}, \mathrm{Co}^{2+}, \mathrm{Mn}^{2+}, \mathrm{Fe}^{3+}$; inhibitors $(2 \mathrm{mmol} / \mathrm{L})$ : ethylene diamine tetra-acetic acid (EDTA) as a di- and tri-valent metal ion chelating agent, $\beta$-mercaptoethanol as a redox reagent, and phenyl methyl sulphonyl fluoride (PMSF) as a serine hydrolase inhibitor; and surfactants $(0.1 \%(v / v))$ : Tween 80 , Triton X-100, and SDS.

\subsection{Substrate specificity}

Substrate specificity was assayed using different $p$-nitrophenyl fatty acid esters with various acyl chain lengths such as $p$-NP butyrate $\left(\mathrm{C}_{4}\right), p$-NP caproate $\left(\mathrm{C}_{6}\right), p$-NP caprylate $\left(\mathrm{C}_{8}\right), p$-NP decanoate $\left(\mathrm{C}_{10}\right), p$-NP laurate $\left(\mathrm{C}_{12}\right), p$-NP myristate $\left(\mathrm{C}_{14}\right), p$-NP palmitate $\left(\mathrm{C}_{16}\right)$, and $p$-NP stearate $\left(\mathrm{C}_{18}\right)$ under standard conditions.

\subsection{Kinetic parameters}

The Michaelis-Menten kinetic parameters $K_{\mathrm{m}}, V_{\mathrm{max}}, K_{\text {cat, }}$ and $K_{\text {cat }} / K_{\mathrm{m}}$ of the lipase were calculated using $p$-nitrophenyl caprylate $\left(p-\mathrm{NPC}_{8}\right)$ and $p$-nitrophenyl palmitate $(p$-NPC 16$)$ as substrates, respectively. The initial reaction velocity of different substrate concentration (50-400 mmol/L) was measured under standard assay conditions. Lineweaver-Burk plots were used to determine kinetic constants $K_{\mathrm{m}}$ and $V_{\text {max }}$.

\subsection{Effects of organic solvents on enzyme activity}

To study the activity and stability of lp2252 in organic sol- vents, aliquots of the purified lipase were incubated in the presence of each organic solvent $(30 \%, v / v)$ in phosphate buffer $(20 \mathrm{mmol} / \mathrm{L}, \mathrm{pH}$ 7.0). The residual activity was measured after incubating the mixture at $30{ }^{\circ} \mathrm{C}$ with constant shaking of $180 \mathrm{r} / \mathrm{min}$ for $1 \mathrm{~h}$ and $16 \mathrm{~h}$.

\subsection{Effects of organic solvents on the synthesis of octyl oc- tanoate}

The ester synthesis reaction was carried out in a 6-mL reaction system that contained $5 \mathrm{~mL}$ of various organic solvents respectively, and $0.28 \mathrm{~mol} / \mathrm{L}$ of 1 -octanol and octanoic acid. The added amounts of lipase and $\mathrm{H}_{2} \mathrm{O}$ were 150 and $250 \mathrm{mg}$, respectively. The mixture was reacted at $40{ }^{\circ} \mathrm{C}, 120 \mathrm{r} / \mathrm{min}$ for $12 \mathrm{~h}$. Samples were withdrawn from the reaction medium and diluted with $5 \mathrm{~mL}$ of ethanol/acetone $(1: 1 \mathrm{v} / \mathrm{v})$ and titrated with $0.05 \mathrm{~mol} / \mathrm{L} \mathrm{NaOH}$ in the presence of phenolphthalein $1 \%$, $w / v$ ) for determination of the remaining acid. Ester conversion was calculated according to the equation below. The assays were performed in triplicate and average values were taken.

$$
\text { Conversion }(\%)=\left(1-\frac{V \times c \div 1000}{V_{0} \times 0.915 \div 144.24}\right) \times 100 \%
$$

here, $V, c, V_{0}, 0.915,144.24$ represent the volume of $\mathrm{NaOH}$ consumed during titration (mL), the concentration of $\mathrm{NaOH}$ $(\mathrm{mol} / \mathrm{L})$, the initial volume of octanoic acid $(\mathrm{mL})$, the relative density of octanoic acid $(\mathrm{g} / \mathrm{mL})$, and the relative molecular mass of octanoic acid, respectively.

\section{Results and discussion}

\subsection{Lipase gene and deduced amino acid sequence analysis}

The full length of lp2252 was amplified from the genomic DNA of P. pasadenensis CS0611 using a pair of degenerate oligonucleotide primers. An open reading frame (ORF) of $1068 \mathrm{bp}$ encoding a polypeptide of 356 aa residues was indicated after sequencing and gene analysis. The deduced recombinant lipase was composed of 405 amino acids including an additional 34 $\mathrm{N}$-terminal and $15 \mathrm{C}$-terminal amino acid residues containing the $6 \times$ His tags, which corresponded to a molecular weight of $44.3 \mathrm{kDa}$.

After amino acid sequence alignment and analysis with NCBI BLAST, lp2252 showed high similarity with alpha/beta hydrolase from Paenibacillaceae bacterium GAS479 (NCBI Reference Sequence: WP_090779060.1) and lysophospholipase from Thermobacillus sp. ZCTH02-B1 (GenBank: OUM94863.1), $60 \%$ and $53 \%$ respectively. A multisequence alignment of the deduced amino acid sequence of Ip2252, Paenibacillaceae bacterium GAS479, and Thermobacillus sp. ZCTH02-B1 is shown in Fig. 1. We inferred that Ser, Asp, and His might be the catalytic triad (marked with red triangles). In addition, the conserved pentapeptide motif of Gly-X-Ser-X-Gly surrounding the active-site serine (marked by a rectangle) is typical of $\alpha / \beta$ hydrolases such as lipases and esterases.

\subsection{Expression and purification of lp2252}




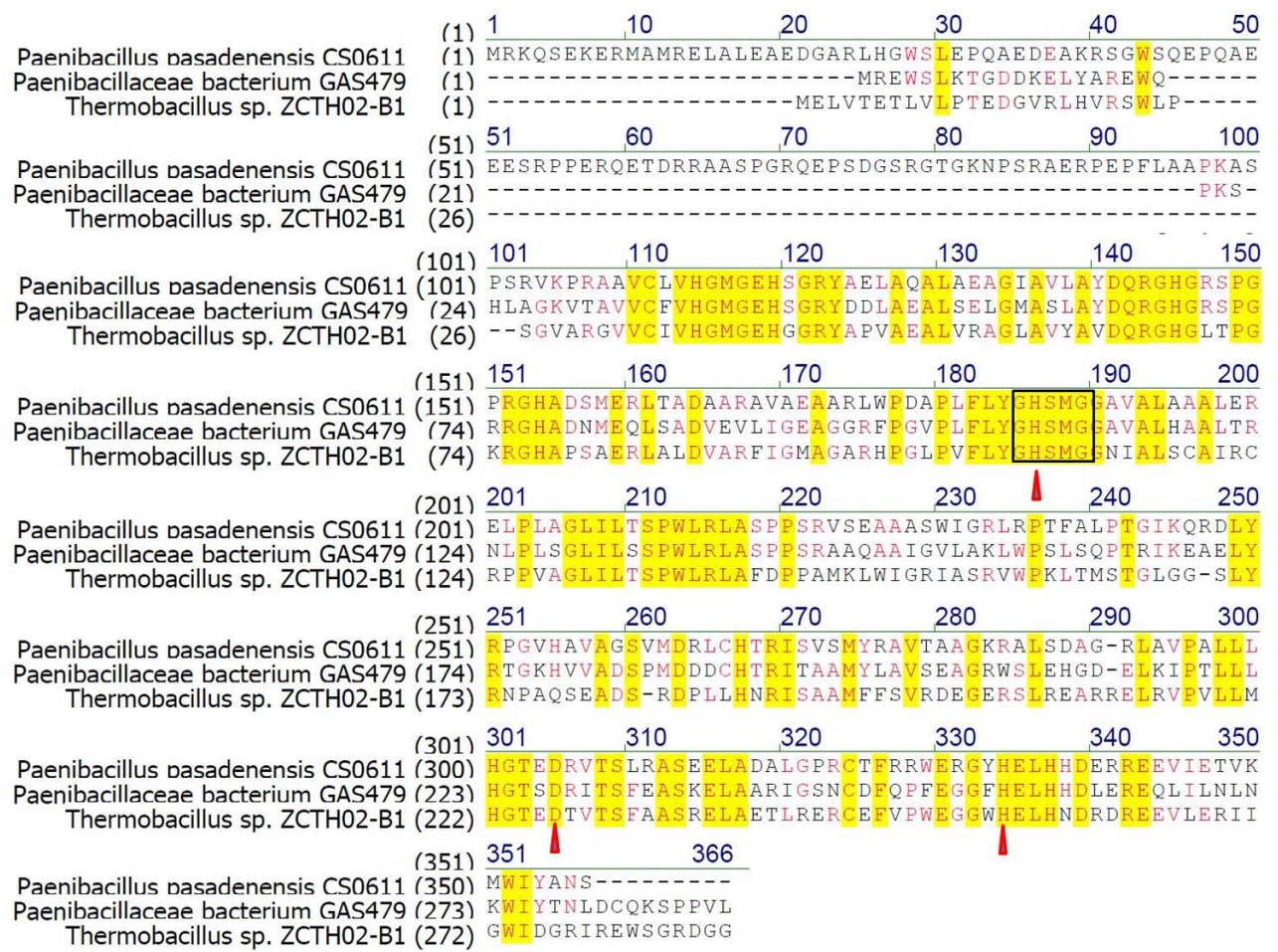

Fig. 1. Multiple sequence alignment for lp2252 from P. pasadenensis CS0611, $\alpha / \beta$ hydrolases from Paenibacillaceae bacterium GAS479, and lysophospholipase from Thermobacillus sp. ZCTH02-B1. The conserved pentapeptide (GHSMG) is marked by a rectangle. The hypothesized catalytic triad (Ser, Asp, and His) is marked with red triangles.

Table 1

Summary of His-tagged recombinant lp2252 purification.

\begin{tabular}{lccccc}
\hline Purification step & Total protein $(\mathrm{mg})$ & Total activity $(\mathrm{U})$ & Specific activity (U/mg) & Yield (\%) & Purification factor \\
\hline Crude enzyme & 28.51 & 3082.16 & 108.10 & 100.0 & 1.0 \\
IMAC & 1.75 & 1958.16 & 1165.57 & 63.5 & 10.78 \\
\hline
\end{tabular}

Optimization of the expression conditions was obtained using properly controlled experiments as described above. After cultivation of recombinant cells at $37{ }^{\circ} \mathrm{C}$ in LB medium containing $50 \mu \mathrm{g} / \mathrm{mL}$ of kanamycin, IPTG was added to a final concentration of $0.1 \mathrm{mmol} / \mathrm{L}$ when the OD600 values reached 1.1. Then the culture was shaken for $16 \mathrm{~h}$ at $20^{\circ} \mathrm{C}$, and cells were harvested by centrifugation. The His-tagged lipase was purified using an IMAC (immobilized metal affinity chromatography) Ni-charged column. As shown in Table 1, purification was achieved with an overall yield of $63.5 \%$ and a purification factor of 10.78. The molecular weight of the purified unfolded His-tagged recombinant lipase was estimated to be $45 \mathrm{kDa}$, which is similar to lipases from other species $[20,21]$. This corresponded with the size of the purified protein by SDS-PAGE (Fig. 2).

\subsection{Effects of temperature and $\mathrm{pH}$ on activity and stability}

Various temperatures (from 20 to $70{ }^{\circ} \mathrm{C}$ ) and $\mathrm{pH}$ values (from 3.0 to 10.0) were used to determine the effect of temperature and $\mathrm{pH}$ on the activity of lp2252. As shown in Fig. 3, the maximum activity was obtained at $50{ }^{\circ} \mathrm{C}$, and the purified enzyme kept more than $60 \%$ of its initial activity in a temperature range of $45-70^{\circ} \mathrm{C}$. After incubation at temperatures from 20 to
$50{ }^{\circ} \mathrm{C}$ for $20 \mathrm{~h}$, the enzyme retained over $70 \%$ residual activity compared with the initial activity. However, when the incubated temperature reached $60{ }^{\circ} \mathrm{C}$, the residual activity decreased to less than $50 \%$.

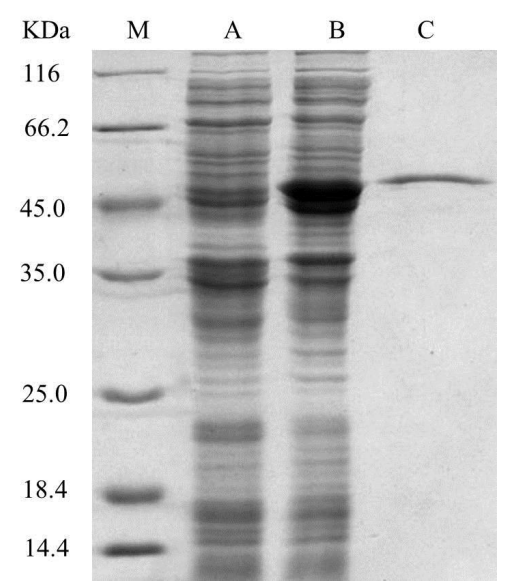

Fig. 2. SDS-PAGE analysis of proteins during purification. (M) molecular weight markers (bottom to top) of 14.4, 18.4, 25.0, 35.0, 45.0, 66.2, and $116 \mathrm{kDa}$; (A) Total proteins of E. coli BL21 harboring blank pET-28a; (B Total proteins of E. coli BL21 harboring recombinant pET-28a; (C) lp2252 purified by Ni-NTA affinity chromatography. 

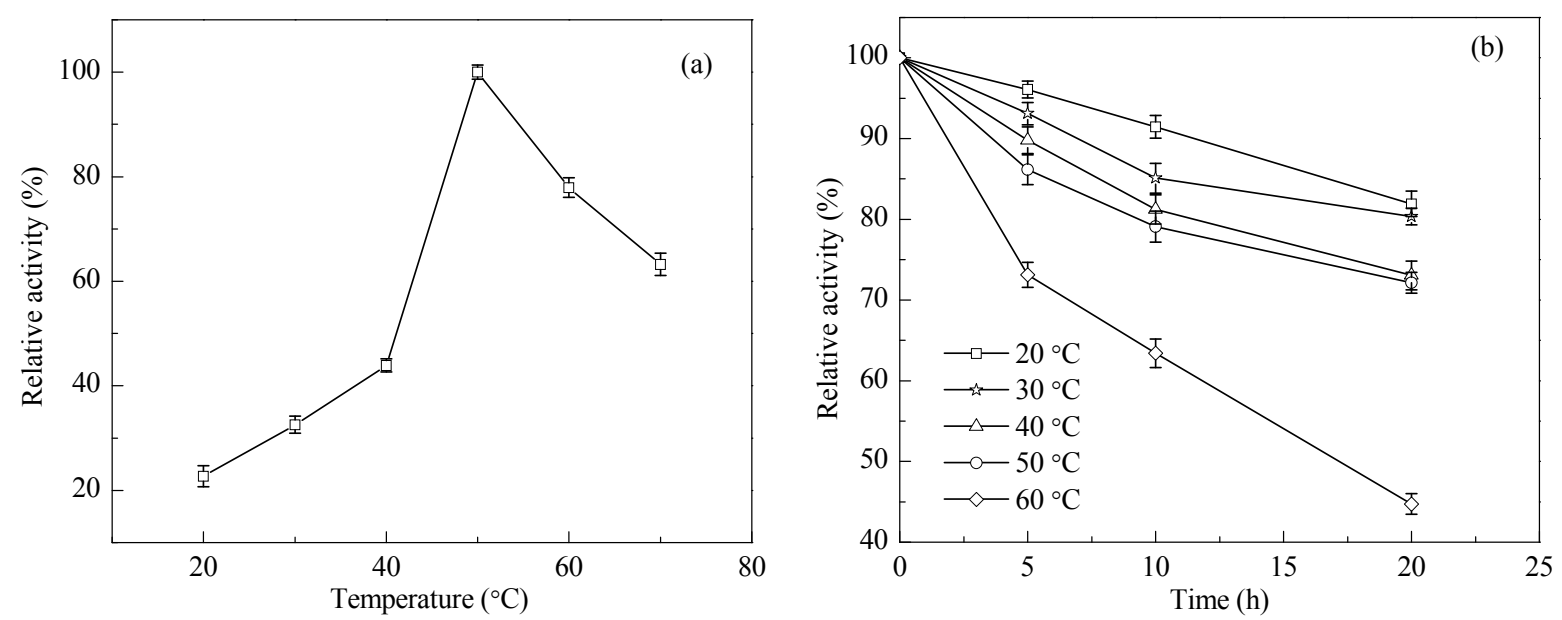

Fig. 3. (a) Effect of temperature on the activity of lp2252; (b) Effect of temperature on the stability of lp2252. Activity was determined by measuring the relative activity at different temperatures $\left(20-70{ }^{\circ} \mathrm{C}\right)$, and temperature-stability was determined by measuring the residual activity at $50{ }^{\circ} \mathrm{C}$ after incubating the purified lipase $(0.1 \mathrm{mg} / \mathrm{mL})$ at a temperature range of $20-60^{\circ} \mathrm{C}$ for 5,10 , and $20 \mathrm{~h}$.

The purified enzyme showed an optimum hydrolytic activity at pH 7.0 (Fig. 4), which is similar to most lipases whose optimum $\mathrm{pH}$ are in a range of $\mathrm{pH} 7.0-8.0$ [3]. There are some lipases that show the highest activity at alkaline $\mathrm{pH}$, such as those from G. thermoleovorans YN (pH 9.5) [22] and Pseudomonas fluorescens JCM5963 (pH 9.0) [23]. As to stability at different pHs, the enzyme retained more than $85 \%$ of its initial activity after incubation at $4{ }^{\circ} \mathrm{C}$ in buffer $(\mathrm{pH}=7.0$ and 8.0$)$ for $30 \mathrm{~h}$. When the $\mathrm{pH}$ of the buffer decreased to 3.0-6.0, the residual activity was also more than $60 \%$ of the initial activity $30 \mathrm{~h}$ later. These results show that the recombinant enzyme is stable over a broad pH range of 3.0-8.0.

\subsection{Effects of metal ions, inhibitors, and surfactants on lp2252}

The effects of different metal ions, inhibitors, and surfactants on the activity of the purified enzyme are shown in Table 2. The presence of $\mathrm{Ca}^{2+}$ and $\mathrm{Mg}^{2+}$ strongly activated lipase ac-

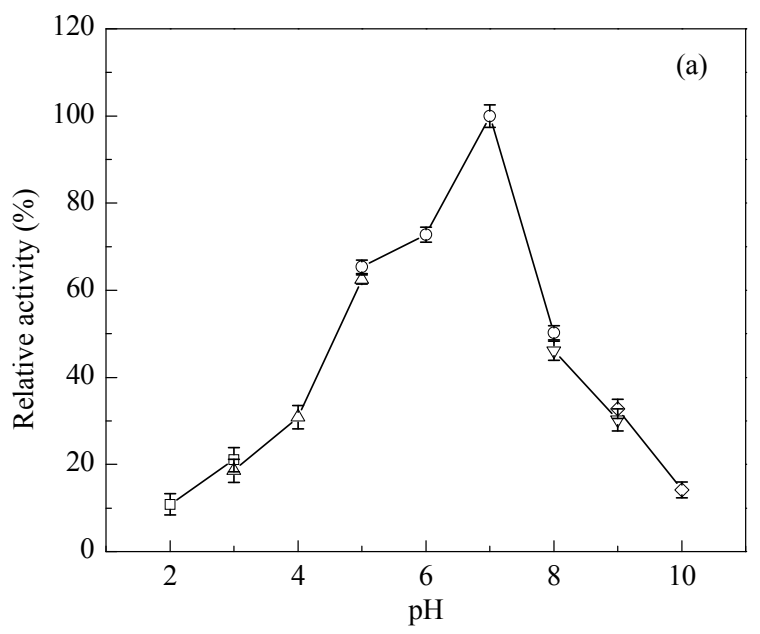

tivity up to $208 \%$ and $146 \%$, respectively, compared to the control. This ion stimulation is similar to that of lipase from Acinetobacter sp. RAG-1 [24]. $\mathrm{Cu}^{2+}$ gave a moderate activation of $16 \%$. In contrast, $\mathrm{Zn}^{2+}, \mathrm{Fe}^{2+}, \mathrm{Co}^{2+}, \mathrm{Mn}^{2+}$, and $\mathrm{Fe}^{3+}$ inhibited the activity of lp2252 lipase. The presence of $\mathrm{Fe}^{3+}$ made the relative activity of lp2252 decrease to $37 \%$ that of the control. In addition, the activity of lp2252 was strongly inhibited by the metal-chelating agent EDTA, which decreased to $39 \%$ of the control, suggesting that lp2252 is a metalloenzyme. This is consistent with many lipases reported previously [3]. PMSF almost inhibited the activity of lp2252 completely, which indicated the presence of a serine residue at the active site. $\beta$-mercaptoethanol as a redox reagent also had an inhibitory effect on lipase activity, suggesting the presence of disulfide bond(s) in the lipase structure. Non-ionic surfactants Triton $\mathrm{X}-100$ and Tween-80 at $0.1 \%(v / v)$ increased the activity by $30 \%$ and $15 \%$, respectively, which the anionic surfactant SDS inhibited the hydrolytic activity of lp2252 completely. Lipase

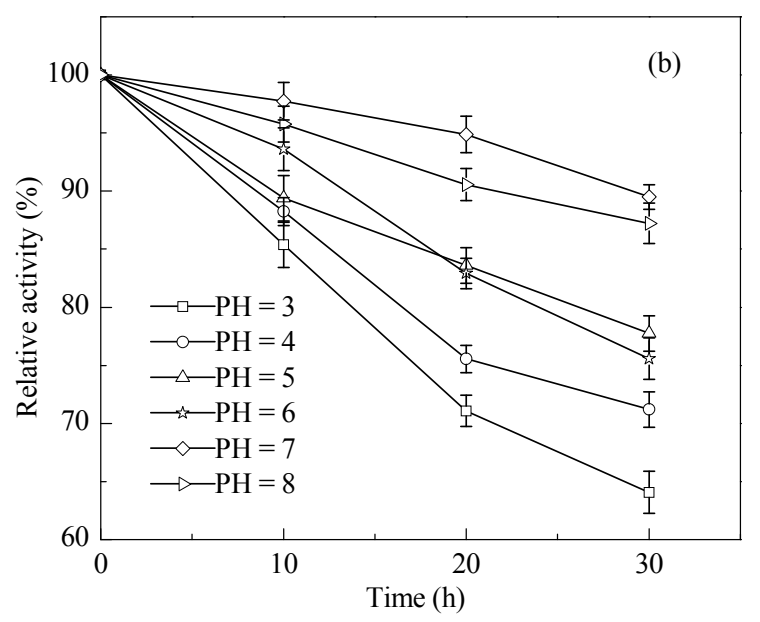

Fig. 4. (a) Effect of $\mathrm{pH}$ on activity of lp2252. Buffers: glycine- $\mathrm{HCl}(\mathrm{pH} 2.0-3.0)$, $\mathrm{HAc}-\mathrm{NaAc}(\mathrm{pH} 3.0-5.0), \mathrm{Na}_{2} \mathrm{HPO}_{4}$-citric acid (pH 5.0-8.0), Tris-HCl: (pH 8.0-9.0,), glycine- $\mathrm{NaOH}\left(\mathrm{pH} 9.0-10.0\right.$ ). (b) Effect of $\mathrm{pH}$ on stability of lp2252. Buffer: $\mathrm{Na}_{2} \mathrm{HPO}_{4}$-citric (3.0-8.0). (a) Purified lipase samples were diluted in $20 \mathrm{mmol} / \mathrm{L} \mathrm{Na}_{2} \mathrm{HPO}_{4}-\mathrm{NaH}_{2} \mathrm{PO}_{4}(\mathrm{pH} 7.0$ ) to $0.1 \mathrm{mg} / \mathrm{mL}$. The activity was assayed in various buffers from $\mathrm{pH} 2.0$ to $\mathrm{pH} 10.0$ under standard conditions. (b) The $\mathrm{pH}$ stability was determined by measuring the residual activity at $50{ }^{\circ} \mathrm{C}$ after incubating the purified lipase in buffers of different $\mathrm{pH}$ at 4 ${ }^{\circ} \mathrm{C}$ for 10,20 , and $30 \mathrm{~h}$. 
Table 2

Effects of various chemical agents on purified recombinant lp2252 activity.

\begin{tabular}{lcc}
\hline Chemical agents & $\begin{array}{c}\text { Concentration } \\
(\mathrm{mmol} / \mathrm{L})\end{array}$ & $\begin{array}{c}\text { Relative activity } \\
(\%)\end{array}$ \\
\hline Blank & - & 100 \\
$\mathrm{Ca}^{2+}$ & 2 & $208.07 \pm 5.26$ \\
$\mathrm{Mg}^{2+}$ & 2 & $146.87 \pm 5.66$ \\
$\mathrm{Cu}^{2+}$ & 2 & $116.12 \pm 3.53$ \\
$\mathrm{Zn}^{2+}$ & 2 & $79.62 \pm 4.85$ \\
$\mathrm{Fe}^{2+}$ & 2 & $72.43 \pm 8.81$ \\
$\mathrm{Co}^{2+}$ & 2 & $68.84 \pm 2.32$ \\
$\mathrm{Mn}^{2+}$ & 2 & $67.69 \pm 5.76$ \\
$\mathrm{Fe}^{3+}$ & 2 & $36.93 \pm 2.89$ \\
EDTA & 2 & $39.02 \pm 2.46$ \\
PMSF & 2 & $16.13 \pm 3.76$ \\
$\beta-m e r c a p t o e t h a n o l$ & 2 & $60.26 \pm 4.15$ \\
Triton-100 & $0.1 \%(w / v)$ & $130.87 \pm 5.32$ \\
Tween-80 & $0.1 \%(w / v)$ & $115.34 \pm 3.16$ \\
SDS & $0.1 \%(w / v)$ & $0 \pm 0$ \\
\hline
\end{tabular}

from Bacillus thermoleovorans CCR11 [25] is enhanced in the presence of Triton X-100 and completely inhibited by SDS and Tween-80. Based on the results above, the appropriate concentration of metal ions like $\mathrm{Ca}^{2+}$ or $\mathrm{Mg}^{2+}$ and proper surfactants can be added to the reaction system to obtain higher hydrolytic activity.

\subsection{Substrate specificity}

As regards to substrate specificity (Table 3 ), the purified enzyme exhibited activity toward $p$-nitrophenyl fatty acid esters with a broad range of acyl chain lengths, and the highest activity was obtained with $p$-NPC ${ }_{8}$. The hydrolytic activity against long-chain fatty acid esters of $p$-nitrophenyl was lower than those of short- and medium-chain lengths; activities were $51.8 \%\left(p-\mathrm{NPC}_{16}\right)$ and $49.6 \%$ ( $p$ - $\mathrm{NPC}_{18}$ ) of the maximum activity to $p$-NPC. A similar specificity has been reported for lipase from P. fluorescens JCM5963 [23], while some other lipases have shown preference for esters with shorter fatty acids $\left(\mathrm{C}_{4}\right.$ and $\left.\mathrm{C}_{6}\right)[26,27]$.

\subsection{Kinetic parameters}

Kinetic parameters were determined by spectrophotometric

Table 3

Substrate specificity of lp2252 lipase towards $p$-nitrophenyl fatty acid esters with various acyl chain lengths.

\begin{tabular}{lcc}
\hline Substrate & $\begin{array}{c}\text { Specific activity } \\
(\mathrm{U} / \mathrm{mg})\end{array}$ & $\begin{array}{c}\text { Relative activity } \\
(\%)\end{array}$ \\
\hline$p$-Nitrophenyl butyrate $\left(\mathrm{C}_{4}\right)$ & $220.25 \pm 7.41$ & $71.28 \pm 4.50$ \\
$p$-Nitrophenyl caproate $\left(\mathrm{C}_{6}\right)$ & $240.00 \pm 6.21$ & $77.67 \pm 7.11$ \\
$p$-Nitrophenyl caprylate $\left(\mathrm{C}_{8}\right)$ & $309.00 \pm 5.54$ & $100.00 \pm 6.59$ \\
$p$-Nitrophenyl decanoate & $229.25 \pm 6.16$ & $74.19 \pm 5.55$ \\
& & \\
(C 10$)$ & & \\
$p$-Nitrophenyl laurate $\left(\mathrm{C}_{12}\right)$ & $212.50 \pm 5.31$ & $68.77 \pm 5.48$ \\
$p$-Nitrophenyl myristate $\left(\mathrm{C}_{14}\right)$ & $166.50 \pm 5.88$ & $53.88 \pm 6.42$ \\
$p$-Nitrophenyl palmitate $\left(\mathrm{C}_{16}\right)$ & $160.00 \pm 7.72$ & $51.78 \pm 4.46$ \\
$p$-Nitrophenyl stearate $\left(\mathrm{C}_{18}\right)$ & $153.25 \pm 7.65$ & $49.60 \pm 3.21$ \\
\hline
\end{tabular}

Table 4

Kinetic constants of lp2252 toward different substrates.

\begin{tabular}{lcccc}
\hline Substrate & $\begin{array}{c}K_{\mathrm{m}} \\
(\mathrm{mmol} / \mathrm{L})\end{array}$ & $\begin{array}{c}K_{\text {cat }} \\
\left(\mathrm{s}^{-1}\right)\end{array}$ & $\begin{array}{c}K_{\text {cat }} / K_{\mathrm{m}} \\
\left(\mathrm{L} \mathrm{mmol}^{-1} \mathrm{~s}^{-1}\right)\end{array}$ & $\begin{array}{c}V_{\max } \\
(\mu \mathrm{mol} / \mathrm{min})\end{array}$ \\
\hline$p$-NPC 8 & $0.12 \pm 0.03$ & $198.0 \pm 5.61$ & $1650.0 \pm 12.37$ & $3.33 \pm 0.16$ \\
$p$-NPC $_{16}$ & $0.34 \pm 0.01$ & $446.7 \pm 9.53$ & $1313.8 \pm 20.48$ & $7.45 \pm 0.54$ \\
\hline
\end{tabular}

assays using $p$-NPC 8 and $p$-NPC 16 as substrates. Lp2252 showed simple hyperbolic Michaelis-Menten kinetics for two substrates (Table 4). As shown, the recombinant lipase was more selective toward $p$-NPC ${ }_{8}\left(K_{\mathrm{m}}\right.$ value of $\left.0.12 \mathrm{mmol} / \mathrm{L}\right)$ than $p-\mathrm{NPC}_{16}(0.34$ $\mathrm{mmol} / \mathrm{L})$.

\subsection{Stability of Ip2252 in organic solvents}

The stability and activity of lipases in organic solvents are important characteristics when they are used for chiral separation or organic synthesis. The relative hydrolytic activities of lp2252 in the presence of different organic solvents $(30 \%, v / v)$ after incubation for 1 and $16 \mathrm{~h}$ are shown in Fig. 5. Among 13 different polar and non-polar organic solvents, whose empirical polarity parameters $\left(E_{\mathrm{T}}(30)\right)$ were from 0.006 to 0.762 [28], the activity of lp2252 increased in the presence of methanol (192.31\%), ethanol (493.43\%), butanol (154.78\%), isopropanol (367.23\%), tertiary butanol (134.14\%), acetone (245.12\%), and tetrahydrofuran (129.27\%). After incubation for $16 \mathrm{~h}$, the activation caused by ethanol (197.46\%) and isopropanol (198.65\%) was still distinct. However, lp2252 was inactivated to some extent in the presence of hexane (58.16\%), cyclohexane $(62.85 \%)$, and diethyl ether $(69.42 \%)$. The polarity of these organic solvents was relatively high but less than water, so they can reduce the polarity of the environment allowing enzyme molecules to fold correctly and substrate and enzyme molecules to combine easily. However, the structure of lipase is typically hydrophilic in whole, with a hydrophobic core and hydrophilic surface. And its activity must be maintained by solvent with a certain polarity. When the solvent polarity is too low, the structure of the enzyme will be destroyed, leading to activity reduction or inactivation. Compared with a reported organic solvent-tolerant lipase, lp2252 activation by short carbon chain alcohols including isopropanol, methanol, and ethanol, as well as acetone, was remarkable. The relative activities of lipase from P. fluorescens JCM5963 [23] were about 110\% after incubation for $1 \mathrm{~h}$ in the presence of each of these four solvents, respectively. For lipase from Galactomyces geotrichum Y05 [29], 50\% $(v / v)$ ethanol, acetone, isopropanol, and butanol decreased enzyme activity to $13 \%-27 \%$. The activities and stabilities of different lipases are diverse in various organic solvents, and further mechanistic investigations are needed.

\subsection{Effects of organic solvents on the synthesis of octyl octano- ate}

Fig. 6 shows the effects of various organic solvents on the lp2252-catalyzed synthesis of octyl octanoate. The ester conversion with decane $(85.49 \%, \log \mathrm{P} 5.6)$ as the reaction medium was the highest, followed by isooctane (82.61\%, $\log \mathrm{P} 4.5)$, 


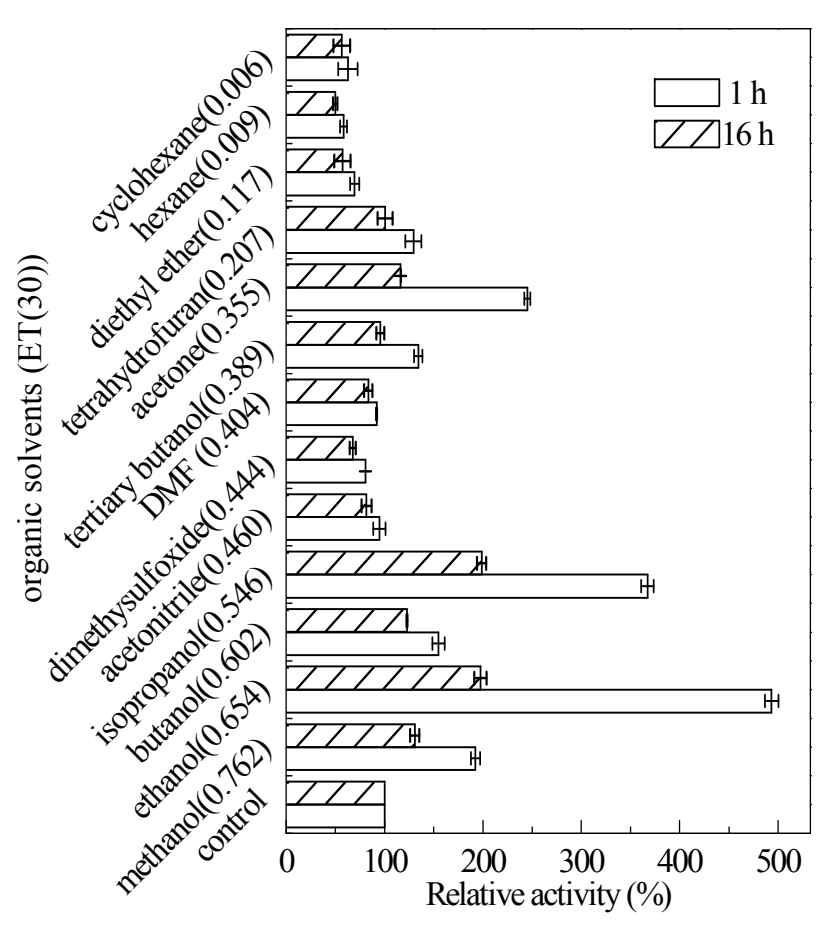

Fig. 5. Effects of various organic solvents on the activity and stability of lp2252. Lipase activity was assayed by detecting the residual activity after incubating purified lipase $(0.1 \mathrm{mg} / \mathrm{mL})$ in the presence of various organic solvents $(30 \%, v / v)$ in phosphate buffer $(20 \mathrm{mmol} / \mathrm{L}, \mathrm{pH} 7.0)$ for $1 \mathrm{~h}$ and $16 \mathrm{~h}$, respectively.

hexane (80.12\%, $\log P$ 3.5), and cyclohexane (78.55\%, logP 3.2). Other solvents with $\log \mathrm{P}<2.5$ tended to give relatively low esterification. This was probably due to (1) high hydrophilicity solvents depriving the essential water around the enzyme present as a microaqueous layer, thereby affecting the active con-

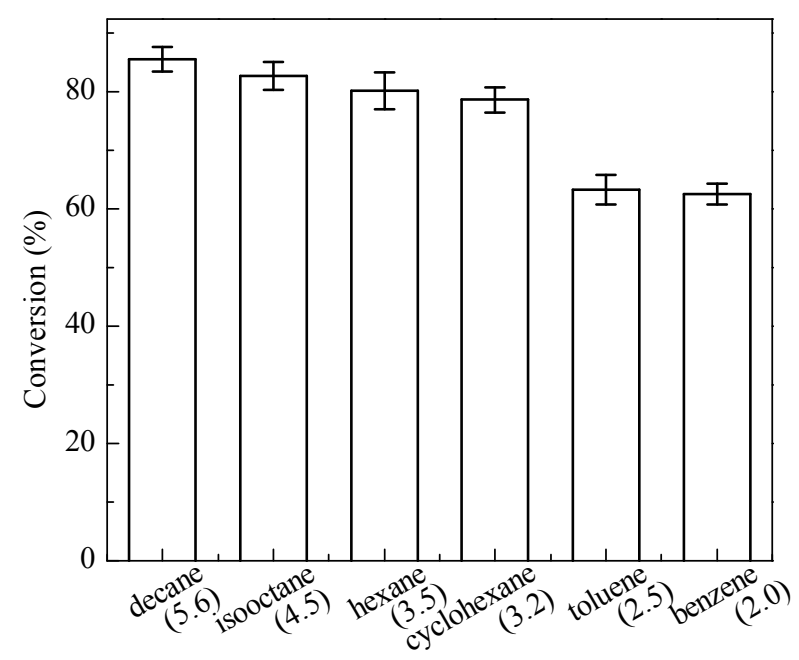

Solvents $(\log \mathrm{P})$

Fig. 6. Effects of various organic solvents on the synthesis of oleyl oleate. Reaction conditions: $12 \mathrm{~h}, 40^{\circ} \mathrm{C}$, substrate (1-octanol and oleic acid $0.28 \mathrm{~mol} / \mathrm{L}$, enzyme $150 \mathrm{mg}$, water $250 \mathrm{mg}$, agitation speed $120 \mathrm{r} / \mathrm{min}$. formation of the enzyme, and (2) low polarity solvents enhancing dissociation of weak organic acid, leading to the reverse reaction (hydrolysis). Our observation is in agreement with previous results in which relatively low ester conversions happen in solvents with $\log \mathrm{P}<2.5[30,31]$.

\section{Conclusions}

In this study, a novel lipase gene from a newly isolated $P$. pasadenensis CS0611 strain was cloned, expressed, purified, and biochemically characterized, adding to our knowledge about the genes and enzymatic properties of lipases from Paenibacillus. The purified recombinant lipase exhibited high activity and stability in a range of temperatures and $\mathrm{pH}$ values. In addition, metal ions such as $\mathrm{Ca}^{2+}$ and $\mathrm{Mg}^{2+}$ had an activating effect on purified lipase to some extent. The most significant characteristic of lp2252 was its tolerance to a range of organic solvents. These features make it a promising candidate in the field of non-aqueous biocatalysis and for industrial lipase-catalyzed processes.

\section{References}

[1] K. E. Jaeger, B. W. Dijkstra, M. T. Reetz, Annu. Rev. Microbiol., 1999, $53,315-351$.

[2] K. E. Jaeger, T. Eggert, Curr. Opin. Biotechnol., 2002, 13, 390-397.

[3] R. Gupta, N. Gupta, P. Rathi, Appl. Microbiol. Biotechnol., 2004, 64, 763-781.

[4] D. Deng, Y. Zhang, A. J. Sun, Y. F. Hu, Chin. J. Catal,, 2016, 37, 1966-1974.

[5] F. Hasan, A. A. Shah, A. Hameed, Enzyme Microb. Technol., 2006, $39,235-251$.

[6] T. K. Zt Rk, G. Ustun, H. A. Aksoy, Bioresource Technol., 2010, 101, 7456-7461.

[7] P. Wang, J. N. Zhu, J. Y. He, Chin. J. Catal., 2010, 31, 651-655.

[8] A. M. Klibanov, Nature, 2001, 409, 241-246.

[9] F. Cardenas, M. S. de Castro, J. M. Sanchez-Montero, J. V. Sinisterra, M. Valmaseda, S. W. Elson, E. Alvarez, Enzyme Microb. Technol., 2001, 28, 145-154.

[10] W. Li, W. Du, Q. Li, R. W. Li, D. H. Liu, Bioresource Technol., 2010, 101, 5737-5742.

[11] Y. W. Fang, Z. X. Lu, F. X. Lv, X. M. Bie, S. Liu, Z. X. Ding, W. F. Xu, Curr. Microbiol., 2006, 53, 510-515.

[12] C. Zhang, L. J. Zhang, Y. Zhang, H. Huang, Y. Hu, Acta Chim. Sin., 2016, 74, 74-80.

[13] Q. C. Ji, S. J. Xiao, B. F. He, X. N. Liu, J. Mol. Catal. B, 2010, 66, 264-269.

[14] F. Rosenau, K. E. Jaeger, Biochimie, 2000, 82, 1023-1032.

[15] M. B. Nthangeni, H. G. Patterton, A. van Tonder, W. P. Vergeer, D. Litthauer, Enzyme Microb. Technol., 2001, 28, 705-712.

[16] F. Cardenas, E. Alvarez, M. S. de Castro-Alvarez, J. M. Sanchez-Montero, M. Valmaseda, S. W. Elson, J. V. Sinisterra, J Mol Catal B, 2001, 14, 111-123.

[17] J. Sambrook, T. Maniatis, E. F. Fritsch, Molecular Cloning: A Laboratory Manual, 2nd ed., Cold Spring Harbor Laboratory Press, New York, 1989.

[18] R. J. Gao, Y. Feng, K. Ishikawa, H. Ishida, S. Ando, Y. Kosugi, S. G. Cao, J. Mol. Catal. B, 2003, 24-25, 1-8.

[19] M. M. Bradford, Anal. Biochem., 1976, 72, 248-254.

[20] A. Ebrahimpour, R. N. Z. R. Abd. Rahman, M. Basri, A. B. Salleh, 


\title{
Graphical Abstract
}

Chin. J. Catal., 2018, 39: 937-945 doi: 10.1016/S1872-2067(18)63033-5

Cloning, overexpression, and characterization of a novel organic solvent-tolerant lipase from Paenibacillus pasadenensis CS0611

Jiaxin Gao, Xiaoyang Ou, Pei Xu, Minhua Zong, Wenyong Lou*

South China University of Technology

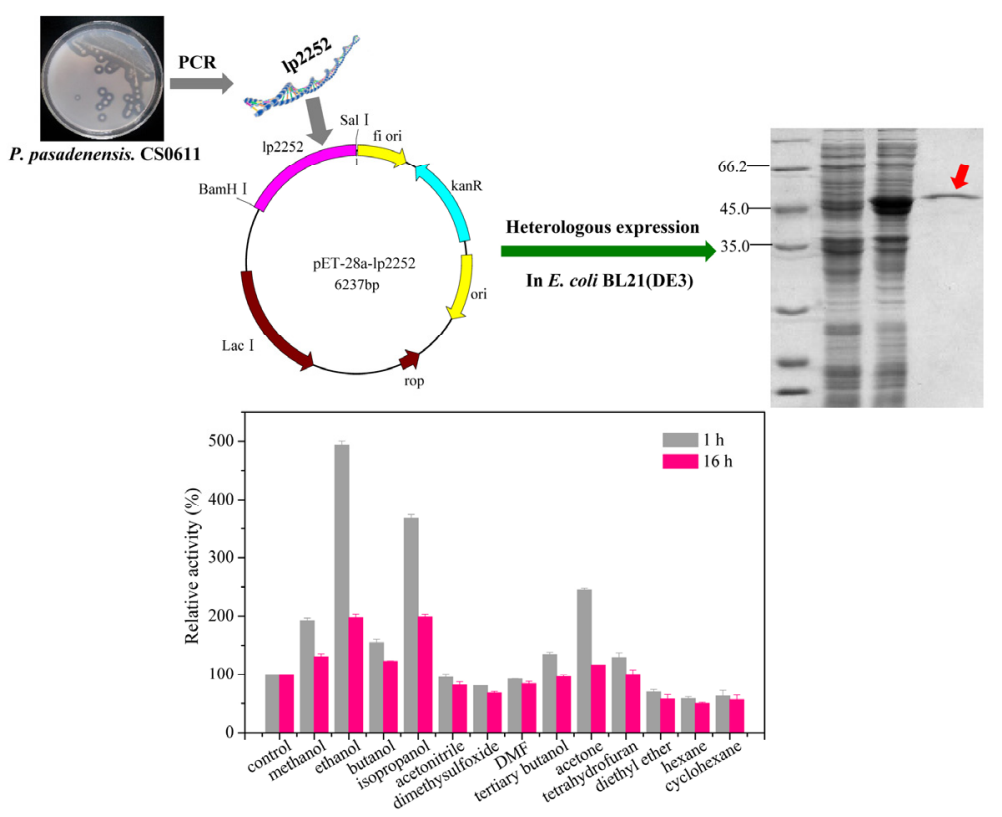

A novel lipase from Paenibacillus pasadenensis CS0611 was cloned, expressed, and characterized for the first time. It showed high activity and stability in a range of organic solvents.

Bioresource Technol., 2011, 102, 6972-6981.

[21] R. N. Z. R. Rahman, T. H. T. A. Hamid, M. A. Eltaweel, M. Basri, A. B. Salleh, J. Biotechnol., 2008, 136, S335-S335.

[22] N. A. Soliman, M. Knoll, Y. R. Abdel-Fattah, R. D. Schmid, S. Lange, Process Biochem., 2007, 42, 1090-1100.

[23] A. J. Zhang, R. J. Gao, N. B. Diao, G. Q. Xie, G. Gao, S. G. Cao, J. Mol. Catal. B, 2009, 56, 78-84.

[24] E. A. Snellman, E. R. Sullivan, R. R. Colwell, Eur. J. Biochem., 2002, 269, 5771-5779.

[25] L. D. Castro-Ochoa, C. Rodriguez-Gmez, G. Valerio-Alfaro, R. A. Oliart Ros, Enzyme Microb. Technol., 2005, 37, 648-654.
[26] S. Imamura, S. Kitaura, J. Biochem., 2000, 127, 419-425.

[27] D. W. Lee, Y. S. Koh, K. J. Kim, B. C. Kim, H. J. Choi, D. S. Kim, M. T. Suhartono, Y. R. Pyun, FEMS Microbiol. Lett., 1999, 179, 393-400.

[28] C. Reichardt, E. Harbusch-Gornert. Liebigs Annalem Chem., 1983, $5,721-743$.

[29] J. Y. Yan, J. K. Yang, L. Xu, Y. J. Yan, J. Mol. Catal. B, 2007, 49, 28-35.

[30] S. M. Radzi, M. Basri, A. B. Salleh, A. Ariff, R. Mohammad, M. Basyaruddin, A. Rahman, R. N. Zaliha, R. A. Rahman, Electron. J. Biotechnol, 2005, 8, 291-298.

[31] K. Harikrishna, B. Manohar, S. Divakar, S. G. Prapulla, N. G. Karanth, Enzyme Microb. Technol., 2000, 26, 131-136.

\section{来源于类芽孢杆菌属新型耐有机溶剂脂肪酶的克隆、表达与性质研究}

\author{
高嘉心 ${ }^{\mathrm{a}}$, 区晓阳 ${ }^{\mathrm{a}}$, 徐培 ${ }^{\mathrm{a}}$, 宗敏华 ${ }^{\mathrm{b}}$, 娄文勇 ${ }^{\mathrm{a}, \mathrm{b},{ }^{*}}$ \\ a华南理工大学食品科学与工程学院, 广东广州 510640 \\ b华南理工大学制浆造纸工程国家重点实验室, 广东广州 510640
}

摘要: 脂肪酶 (EC 3.1.1.3) 全称为三酰基甘油水解酶, 是一类能够将长链脂肪酸甘油酯水解成脂肪酸和二甘酯、单甘酯或甘 油的酯键水解酶. 它除了能够水解脂肪外, 还具有催化酯化反应、酯交换反应、酸解反应、醇解反应以及氨解等反应的性 质. 在脂肪酶催化的反应中, 通常用有机溶剂代替水. 有机溶剂可以转移合成反应的平衡方向, 通过溶剂工程修饰酶的选 择性能够提高底物的溶解度、有机相产物的回收率、酶的热稳定性. 但有机溶剂对酶活性和稳定性有不同程度的影响. 因 此, 寻找在有机溶剂中表现出高活性和稳定性的脂肪酶是一个亟待解决的重要课题. 由于微生物种类多、作用底物专一性 
强, 且微生物来源的脂肪酶一般分泌到胞外, 因此微生物脂肪酶是工业用脂肪酶的重要来源. 目前, 微生物脂肪酶的研究 主要集中于根霉属 (Rhizopus)、曲霉属 (Aspergillus)、青霉属(Penicillium)、毛霉属 (Mucor)、地霉属 (Geotrichum)、假丝酵 母属 (Candida)、假单胞菌属 (Pseudomonas)、伯克霍尔德菌属 (Burkholderia) 等具有工业应用价值的菌株. 很少有类芽孢 杆菌属所产脂肪酶进行相关酶学性质的研究.

我们以 Paenibacillus pasadenensis CS0611 为出发菌株, 在全基因序列草图中得到了一个新型脂肪酶基因 1p2252. 以 Paenibacillus pasadenensis CS0611 基因组为模板, 设计特异性引物对目标序列进行扩增, 并成功将其插入到表达载体 pET-28a 中得到含有目的基因的重组质粒. 在 E.coli BL21(DE3) 中, 脂肪酶 $1 \mathrm{p} 2252$ 经 $0.1 \mathrm{mmol} / \mathrm{L}$ 的 IPTG 诱导后在 $20^{\circ} \mathrm{C}$ 实现了高水平表达. 重组脂肪酶的活性约为野生型的 1631 倍. 用镍离子亲和层析柱快速、高效地纯化了两端带有组氨酸 标签的重组脂肪酶, 回收率为 $63.5 \%$, 纯化因子为 10.78 . 纯化后的脂肪酶最适温度为 $50^{\circ} \mathrm{C}$, 在 $20-40{ }^{\circ} \mathrm{C}$ 范围内具有良好 的稳定性. 最适 $\mathrm{pH}$ 值为 7, 属于中性脂肪酶, 同时在 $\mathrm{pH}$ 3.0-8.0 间具有较高稳定性. 在金属离子如䥻、镁离子和一些非离 子表面活性剂的作用下, 其活性有所提高. 此外, 纯化后的脂肪酶可被一系列水溶性有机溶剂激活, 例如一些短链醇. 而对 某些水不溶性有机溶剂, 其也具有高度的耐受性. 综上所述, 本文所涉新型脂肪酶在非水相催化领域具有广泛的应用和前 景.

关键词: 脂肪酶; 类芽孢杆菌属; 表达; 酶学性质; 有机溶剂耐受性

收稿日期: 2017-11-20. 接受日期: 2018-01-19. 出版日期: 2018-05-05.

*通讯联系人. 电话/传真: (020)22236669; 电子信箱: wylou@scut.edu.cn

基金来源：国家自然科学基金 (21676104, 21336002, 21376096); 制浆造纸工程国家重点实验室项目 (2017ZD05).

本文的电子版全文由Elsevier出版社在ScienceDirect上出版(http://www.sciencedirect.com/science/journal/18722067). 